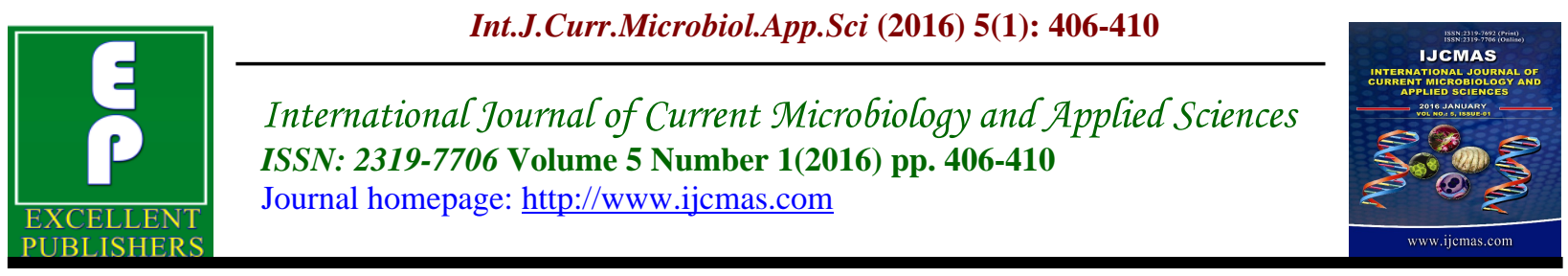

Original Research Article

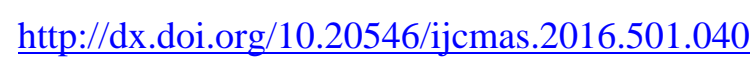

\title{
Effect of Nitrogen, Phosphorus and Potassium on Growth and Green Herb Yield of Thymus serphyllum
}

\author{
Janaki Pal*, R.S.Adhikari and J.S. Negi \\ Department of Botany, Kumaon University, L.S.M. Government, Post Graduate College \\ Pithoragarh, Uttrakhand, India \\ *Corresponding author
}

\begin{tabular}{l} 
Key w or d s \\
Nitrogen(N) \\
Potassium(K), \\
Thyme (thymus \\
serpyllem) \\
\hline Article Info \\
\hline Accepted: \\
December 2015 \\
Available Online: \\
January 2016
\end{tabular}

\section{A B S T R A C T}

Thymus serpyllem (wild thyme) is a member of the Lamiaceae family and is an indigenous aromatic and medicinal plant of Europe and Asia. At present, it is cultivated majorly in North America, Europe and North Africa in a large scale due to its economic importance. Thymus serpyllem is native plant of Mediterranean Europe and north africa . However, it is commercially grown. The objective of this study was to examine the effects of $\mathrm{N}, \mathrm{P}$ and $\mathrm{K}$ on green herb yield and some herb chemical constituents $(\mathrm{N}, \mathrm{P}, \mathrm{K})$ in order to recommend a reliable nutrient management for commercial growers. Results showed that, yield generally increase in accordance with the increases in $\mathrm{N}$, $\mathrm{P}$ and $\mathrm{K}$ fertilizer rates.

\section{Introduction}

Thymus serpyllem L. which is an aromatic and medicinal plant indigenous to Europe and Asia is a member of the Lamiaceae family. T. serpyllum, known as wild thyme, is native to Mediterranean Europe and North Africa, mainly at the higher altitudes. It is acknowledged for its use in home remedies. The plant is aromatic, antiseptic, diaphoretic, analgesic, carminative, expectorant and diuretic; also it acts as an emmanagogue, carminative, and stimulant, also being used in mouth washes, gargles, cough and colds (Farooqi et al., 2005). Its essential oil contains various compounds that are very powerful, proven disinfectants enhancing the immune system and fighting infections. The oil relieves rheumatism, and is also used in hear loss-treatments (Aziz and Rehman, 2008). It is a bush crop, lowgrowing and perennial. The genus Thymus has a long list of species like Thymus citriodorus, Thymus herba-barona, Thymus pseudolanuginosus, Thymus serpyllum and Thymus vulgaris etc. T. vulgaris L. is regarded as the main species species and used commercially. On the other hand, Karık et al. (2007) indicated that the secondary metabolites specific to the aromatic and medicinal plants are mainly controlled genetically but are strongly affected by environmental influences. Moreover, balanced nutrition of the thyme plant has not been examined thoroughly until recently. It is claimed that in order to 
achieve standard crops and standard quality oil yields, the commercial thyme growers need to practice well managed cultivated production systems (Bayram, 2003). In this regard, the significance of $\mathrm{N}$ fertilization is related (Ceylan, 1996) to visible emphasis of $\mathrm{N}$ on vegetative growth and to herbage area increase which directly increases the total oil yield. Baranauskiene et al. (2003) state the disadvantages of excess $\mathrm{N}$ fertilization which often results with high leaf NO3 concentrations. Palada et al. (1998) recommended 50 to $150 \mathrm{~kg}$ ha- $1 \mathrm{~N}$ for $T$. vulgaris $\mathrm{L}$. as a concluding remark to his $\mathrm{N}$ fertilization testing. The same author also reports the beneficial effects of cow manure and urea as $\mathrm{N}$ sources (Palada et al., 1995) which are generally practiced in two splits; in spring and after the first harvest. However, not much information is found on the efficient use of $\mathrm{P}$ and $\mathrm{K}$ fertilizers. Some growers apply $\mathrm{P}$ and $\mathrm{K}$ during the soil preparation in spring in the form of compound fertilizers. Ateia et al. (2009) claimed that the mixture of compost + sheep manure applied at 3:1 ratio give high essential oil yields.

The objective of this study was to recommend a reliable nutrient management for commercial wild thyme growers by examining the effects of different rates of $\mathrm{P}$ and $\mathrm{K}$ fertilizations on green herb yield (leaf + stalk + flower) and some herb nutrients $(\mathrm{N}, \mathrm{P}, \mathrm{K})$.

\section{Materials and Methods}

Seed or one-month-old seedling or small size plant will be selected for cultivation. The net plot size will be kept at $1.35^{*} 1.00 \mathrm{~m}$. twenty seven treatment combinations of fertilizers would be consisted with three levels nitrogen $(0,75,150 \mathrm{~kg}$./ha.). Three levels of phosphorus $(0,125,250 \mathrm{~kg} . / \mathrm{ha}$. $)$ and three level of potassium $(0,75,150 \mathrm{~kg}$./ha.).
Nitrogen will be supplied by urea, single super phosphate and murate of potash respectively. The hole quantity of phosphorus half of potash and nitrogen was applied at the time of planting the rest half dose of nitrogen and potash was given one month after planting. Seedling were planted in well prepared flat beds by spacing $20 * 15$ $\mathrm{cm}$. or according to plant size as suggested by pal and phogat 1984. The observation on plant growth, yield per hectare, leaf area index, rhizome yield will be recorded. Profit would be examined and production will be popularized among local youth.

Experiment plot would be selected on botanical garden L.S.M.P.G.College Pithoragarh, Uttrakhand.

\section{Results and Discussion}

Green herb yields were found generally higher in the second year of the experiment in all of the treatments. Each year, yield response to the enhanced, $\mathrm{K}$ and $\mathrm{P}$ fertilizations were found positive and statistically significant at $1 \%$ level. The interaction effect of $\mathrm{N}, \mathrm{P}$ and $\mathrm{K}$ fertilizations on yield was not found significant in the first year where as was determined significant in the second year (Table 2).

In this context, the highest yield was obtained in the highest rate of $\mathrm{N}(150 \mathrm{Kg}$ urea /ha.) P (250 kg phosphorus/ha.) and K (150 kg potash/ha.) fertilizations. Nutrient elements $(\mathrm{N}, \mathrm{P}$ and $\mathrm{K})$ of the green herb were also analyzed in both of the study years. Results of the statistical analyses showed that the herb $\mathrm{N}, \mathrm{P}$ and $\mathrm{K}$ contents were significantly higher. On the other hand, in the first and second years of this study, statistically significant interaction effects of $\mathrm{N}, \mathrm{P}$ and $\mathrm{K}$ fertilizations were determined on the $\mathrm{N}, \mathrm{P}$ and $\mathrm{k}$ contents of the herb respectively. 
Table.1 Soil Properties of Experimental Site

\begin{tabular}{|c|c|c|c|c|c|c|c|c|c|}
\hline \multirow[t]{2}{*}{ Site } & \multirow{2}{*}{$\begin{array}{l}\text { Colour } \\
\text { (dry) }\end{array}$} & \multirow[t]{2}{*}{ elevation } & \multirow{2}{*}{$\begin{array}{l}\text { Soil } \\
\text { tex }\end{array}$} & \multicolumn{3}{|c|}{ Particle-size distribution(\%) } & \multirow{2}{*}{$\begin{array}{l}\mathrm{Ph} \\
(1: 2.5)\end{array}$} & \multirow{2}{*}{$\begin{array}{l}\text { Org } \\
\text { carbon } \\
\mathrm{Kg}^{-}{ }^{-}\end{array}$} & \multirow{2}{*}{$\begin{array}{l}\mathrm{Cec} \\
\mathrm{Cmo} \\
(\mathrm{p}+) \\
\mathrm{Kg}-1\end{array}$} \\
\hline & & & & $\begin{array}{l}\text { Sand } \\
(2.0-0.05 \\
\mathrm{mm})\end{array}$ & $\begin{array}{l}\text { silt } \\
(0.05- \\
0.002 \mathrm{~mm})\end{array}$ & $\begin{array}{l}\text { Clay } \\
(<0.00 \\
2 \mathrm{~mm})\end{array}$ & & & \\
\hline $\begin{array}{l}\text { L.S.M.G.P.G.C. } \\
\text { Pithoragarh }\end{array}$ & $\begin{array}{l}\text { Olive } \\
\text { yellow }\end{array}$ & 1498 & silt & 7.6 & 68.9 & 23.5 & 5.9 & 14.7 & 9.3 \\
\hline
\end{tabular}

Table.2 Effect of N, K and P Fertilization on Green Herb Yield (kg/ha.) for 2011 and 2012 Seasons

\begin{tabular}{|c|c|c|}
\hline Combination no. & First season (2011) & Second season (2012) \\
\hline C1 & 14600 & 17800 \\
\hline C2 & 15100 & 18500 \\
\hline C 4 & 15700 & 18900 \\
\hline Mean & 16000 & 19200 \\
\hline
\end{tabular}

$\mathrm{C} 1=$ control, $\mathrm{C} 2=\mathrm{N}(150 \mathrm{~kg} / \mathrm{ha})+.\mathrm{P}(125 \mathrm{~kg} / \mathrm{ha})+.\mathrm{K}(75 \mathrm{~kg} / \mathrm{ha}), \mathrm{C} 3=\mathrm{N}(75 \mathrm{~kg} / \mathrm{ha})+.\mathrm{P}(250 \mathrm{~kg} / \mathrm{ha})+.\mathrm{K}(75$ $\mathrm{kg} / \mathrm{ha}$.) and $\mathrm{C} 4=\mathrm{N}(150 \mathrm{~kg} / \mathrm{ha})+.\mathrm{P}(250 \mathrm{~kg} / \mathrm{ha})+.\mathrm{K}(150 \mathrm{~kg} / \mathrm{ha}$. $)$

Table.3 Effect of N,P and K Fertilization on N,P and K Conent (\%) for2011 and 2012 Seasons

\begin{tabular}{|c|c|c|c|c|c|c|}
\hline \multicolumn{7}{|c|}{$\%$} \\
\hline \multirow{2}{*}{$\begin{array}{l}\text { Combination } \\
\text { no. }\end{array}$} & \multicolumn{2}{|c|}{$\mathrm{N}$} & \multicolumn{2}{|c|}{$\mathrm{P}$} & \multicolumn{2}{|c|}{$\mathrm{K}$} \\
\hline & $\begin{array}{l}\text { First season } \\
\text { (2011) }\end{array}$ & $\begin{array}{c}\text { Second } \\
\text { season (2012) }\end{array}$ & $\begin{array}{l}\text { First season } \\
\text { (2011) }\end{array}$ & $\begin{array}{c}\text { Second } \\
\text { season (2012) }\end{array}$ & $\begin{array}{l}\text { First season } \\
\text { (2011) }\end{array}$ & $\begin{array}{l}\text { Second season } \\
\text { (2012) }\end{array}$ \\
\hline $\mathrm{C} 1$ & 1.087 & 1.087 & 0.174 & 0.174 & 0.686 & 0.686 \\
\hline $\mathrm{C} 2$ & 1.250 & 1.265 & 0.178 & 0.180 & 0.690 & 0.692 \\
\hline C3 & 1.153 & 1.183 & 0.185 & 0.190 & 0.700 & 0.704 \\
\hline $\mathrm{C} 4$ & 1.510 & 1.525 & 0.195 & 0.200 & 0.708 & 0.710 \\
\hline Mean & 1.250 & 1.265 & 0.183 & 0.186 & 0.696 & 0.698 \\
\hline
\end{tabular}

$\mathrm{C} 1=$ control,C2 $=\mathrm{N}(150 \mathrm{~kg} / \mathrm{ha})+.\mathrm{P}(125 \mathrm{~kg} / \mathrm{ha})+.\mathrm{K}(75 \mathrm{~kg} / \mathrm{ha}), \mathrm{C} 3=\mathrm{N}(75 \mathrm{~kg} / \mathrm{ha})+.\mathrm{P}(250 \mathrm{~kg} / \mathrm{ha})+.\mathrm{K}(75 \mathrm{~kg} / \mathrm{ha}$.$) and \mathrm{C} 4=\mathrm{N}(150$ $\mathrm{kg} / \mathrm{ha}$. $)+\mathrm{P}(250 \mathrm{~kg} / \mathrm{ha}$. $)+\mathrm{K}(150 \mathrm{~kg} / \mathrm{ha}$. $)$

The data of this study showed that $\mathrm{N}, \mathrm{P}$ and $\mathrm{K}$ fertilizations positively affect the developments in T.sepyllem, its yield as well as its quality as a medicinal and herbaceous plant. Among many plant growth factors, the nutritional requirements of the crops are considered to be the most important factor. Generally the growth, development, yield and the quality of herbs are affected by genetic background; however, environment and the cultural practices are as well important (Karkk, et al., 2007). It is well known that $P$ is an essential element in reproductive and vegetative growth and flower number can increase by the increased $\mathrm{P}$ applications (Mengel and Kirkby, 2001). Phosphorus also has many other cellular functions in plants and affects the primary and secondary metabolites. Therefore, $\mathrm{P}$ fertilization in medicinal herbs is strongly recommended especially in cites with low available soil P (Marschner, 1995). 
Similarly, it is also very well known that K fertilizers improve growth parameters and yield quality (Mengel and Kirkby, 2001). Potassium fertilizers proved its role in plant metabolism, carbohydrate synthesis, water transport in xylem, cell elongation. Singh (2001) reported that addition of $\mathrm{K}$ resulted with higher herb yields.

In this current study, green herb yield, some of the herb nutrient elements like N,P, K positively responded toN, $\mathrm{P}$ and $\mathrm{K}$ fertilizer treatments. The highest herbal yield was determined in $150 \mathrm{~kg}$ urea/ ha.+ $250 \mathrm{~kg}$ phosphorus/ ha. $+150 \mathrm{~kg}$ potash/ha. treatment in both of the study seasons. It is worth reporting that this specified highest yield obtained from the $150 \mathrm{~kg}$ urea/ ha.+ $250 \mathrm{~kg}$ phosphorus/ ha. $+150 \mathrm{~kg}$ potash $/ \mathrm{ha}$.

It can be concluded that if the herb yield evaluated and weighed and ranked according to the treatments, we can reach the conclusion that if economically viable $150 \mathrm{~kg}$ urea, $250 \mathrm{~kg}$ phosphorus and $150 \mathrm{~kg}$ Potash per hectare could be recommended for about $19200 \mathrm{~kg}$ of green herb yield ha- 1 . In case $\mathrm{N}$ fertilization is necessary according to soil testing, recommendations should be followed.

\section{Acknowledgment}

The author is grateful to Dr. R. S. Adhikari, the head of department of Botany, L.S.M.G.P.G.C. Pithoragarh for providing all kinds of facilities during this study.

\section{References}

Alam Ghayur, Lucian Peppelenbos, Cultivation of Medicinal Plants in Uttarakhand, Economic and Political Weekly, March 7, 2009
Baranauskiene R, Venskutonis PR, Viskelis P, Dambrauskiene E (2003). Influence of nitrogen fertilizers on the yield and composition of thyme (Thymus vulgaris). J. Agric. Food Chem. 51(26):7751-7758.

Demissew, S (1993). The genus Thymus (Labiatae) in Ethiopia. Opera. Bot. 121: 57-60.

Dhar, U., Conservation implication of plant endemism in high altitude Himalaya. Curr. Sci., 2002, 82, 141-148.

Javad, S. G., Mohammad, H. M., Shabnam, S., Meysam, H., Abbas, H (2009). Chemical characterization of bioactive volatile molecules of four Thymus species using nanoscale injection method; DigestJournal of Nanomaterials and Biostructures Vol. 4 (4), p. $835-841$.

Kala CP (1998). Ethnobotanical Survey and Propagation of Rare Medicinal Herbs in the Buffer Zone of the Valley of Flowers National Park Garhwal Himalaya. International Centre for Integrated Mountain Development, Kathmandu, Nepal.

Kala CP, Dhyani PP, Sajwan BS (2006). Developing the medicinal plants sector in northern India: Challenges and opportunities. J.Ethnobiol. Ethnomed. 2: 32.

Nautiyal MC, Viany Prakash, Nautiyal BP (2002). Cultivation techniques of some high altitude medicinal herbs. Ann. For. 10: 62-67.

Nautiyal, M. C. and Nautiyal, B. P., In Agrotechniques for High Altitude Medicinal and Aromatic Plants, Bishan Singh, Mahendra Pal Singh, Dehdradun, 2004.

Nautiyal, M. C., Cultivation of medicinal plants and biosphere reserve management in alpine zone. In Conservation and Management of Biological Resources in Himalaya 
(Eds Ramakrishna, P. S. et al.), GBPIHED and Oxford \& IBH, New Delhi, 1994, pp. 570-582.

Palada MC, Crossman SMA, Kowalski JA (1995). Growth and yield response of thyme (Thymus vulgaris L.) to sources of nitrogen fertilizer. In Proceedings of the Caribbean Food Crops Society.
RR, Tigabu M, Oden PC, Vijayachandran SN, Geetha S, Singh BG (2006). Effect of presowing treatments, desiccation and storage conditions on germination of Strychnos nux-vomica seeds, a valuable medicinal plant. New Forest32:121-131.

Shivkumar V, Anandlakshmi R, Warrier

\section{How to cite this article:}

Janaki Pal, R.S.Adhikari and Negi, J.S. 2016. Effect of Nitrogen, Phosphorus and Potassium on Growth and Green Herb Yield of Thymus serphyllum. Int.J.Curr.Microbiol.App.Sci. 5(1): 406410. http:///dx.doi.org/10.20546/ijcmas.2016.501.040 